\title{
An Empirical Research Framework on Digital Marketing Consultancy: the Case of Marcheluzzo Srl
}

\section{Uma Pesquisa Empírica em Consultoria de Marketing Digital: o caso da Marcheluzzo Srl}

\author{
Charles Alves de Castro
}

Technological University Dublin, Stricto Sensu Graduate Program in Administration. Irlanda.

E-mail: charlesturcastro@yahoo.com.br

\begin{abstract}
Drawing from the integrated areas of internal consultancy in marketing, advertising budget, and digital marketing, this empirical research aims to examine the company Marcheluzzo's off-line advertising budget focused on the Brazilian market to combine on-line advertising investments in a new expense budget plan for 2021. A comprehensive analysis of the literature review demonstrates the importance of digital marketing strategies in a B2B - (business-to-business) context within the Brazilian market, covering both their benefits and challenges. The literature review filled and discussed the gaps found, it was also analyzed the past and actual literature within the specific themes in this research. The data used in this research was gathered by a semi-structured one-to-one interview conducted personally with the Marcheluzzo`s marketing and commercial manager. In addition, through the field observation and documents collected in the company more information was possible to gather and have insights about a variety of subjects mainly related to the advertisement budget. It was possible to successfully answer the two main research questions being discussed using the data collected. It was found that Marcheluzzo has been interested in making investments in digital marketing, as well as, there is room for this investment in a new advertisement budget focused on the Brazilian market, combining online and offline marketing strategies.
\end{abstract}

Keywords: Advertising Budget. Digital Marketing. Marketing Consultancy.

\section{Resumo}

A partir das áreas integradas de consultoria interna em marketing, orçamento publicitário e marketing digital, esta pesquisa empírica visa examinar o orçamento publicitário off-line da empresa Marcheluzzo voltado para o mercado brasileiro para combinar investimentos publicitários on-line e off-line em um novo plano orçamentário para 2021. Uma análise abrangente da revisão da literatura demonstra a importância das estratégias de marketing digital em um contexto B2B - (Business-to-Business) no mercado brasileiro, abrangendo seus beneficios e desafios. A revisão bibliográfica preencheu e discutiu as lacunas encontradas, também foi analisada textos já publicados e atuais dentro dos temas especificos desta pesquisa. Os dados utilizados nesta pesquisa foram coletados por meio de entrevista semiestruturada individual realizada pessoalmente com o gerente de marketing e comercial do Marcheluzzo. Além disso, por meio da observação de campo e dos documentos coletados na empresa foi possível reunir mais informações e ter insights sobre uma variedade de assuntos relacionados principalmente ao orçamento publicitário. Foi possível responder com sucesso às duas principais questões de pesquisa em discussão usando os dados coletados. Constatou-se que a empresa Marcheluzzo tem interesse em fazer investimentos em marketing digital no Brasil, bem como, há espaço para esse investimento em um novo orçamento publicitário voltado para o mercado brasileiro, combinando estratégias de marketing online e offline.

Palavras-chave: Orçamento Publicitário. Marketing Digital. Consultoria de Marketing.

\section{Introduction}

Nowadays, we have been living in a metamorphosis world, full of changes and transformations, in which sometimes it has been challenged to follow up on all the rapid alterations, mainly related to the digital age and its aspects such as, new technologies, top-notch automation, internet of things, artificial intelligence, machine learning, big data, etc. Companies, industries, and brands should follow all the new digital trends in order to keep up competitiveness and remain in the market. It could be a challenge for most of them but be placed behind is not the right decision.

As in all fields of business, industries are also facing transformations, which concerns an entire digitalization and robotic automation of manufacturing processes. Some new technologies are illustrating this scenario of a new digital industrial revolution, the so-called Industry 4.0, usually refers to "smart factories" - whereby systems monitor processes and make decentralized decisions, such as the smart manufacturing technologies (autonomous robots, additive manufacturing, laser cutting), cyber-physical systems, big data and cloud computing, Internet of Things (IoT), artificial intelligence, machine learning, voice recognition, augmented reality (BARBSY, 2018; ALMADA-LOBO, 2016). The production processes flexibility and better attention to the customers are required topics to meet the rising markets complexity (BETTIOL; CAPESTRO; DI MARIA, 2017).

Even though the industries are focusing on digitalization and innovation, one significant factor that manufacturing firms have left apart is the digital marketing impact or/and creating 
a digital strategy that helps take their business to the next level of advantage in the new industrial market; hypothetically some firms are investing intensely in robotic automation and digitalization of the production sector, nonetheless forgetting the digital strategies that could be applied in business, for example, forming a digital marketing strategy in which it is critical for engineering and manufacturing firms in order to have a competitive advantage in the market, reduce costs in marketing and reach a wide range of people. The business aspect digitization, as well as how digital marketing activity is planned and implemented, should be considered in great depth for the industry sector (BARBSY, 2018).

Throughout this empirical research, it is evident how the catalyst of this study left the digital marketing field a part of its business strategy. Therefore, drawing from the integrated areas of internal consultancy in marketing, advertising budget, and digital marketing, this empirical research aims to examine the company Marcheluzzo`s off-line advertising budget focused on the Brazilian market to combine on-line advertising investments in a new expense budget plan for 2021. According to the company's commercial manager, the effectiveness of the off-line advertisement strategies over the past few years in the Brazilian market has been ineffective due to the method not generating new leads; consequently, it is not increasing sales. In addition, this research discusses the importance of digital marketing strategies in the context of the B2B industry (business-to-business) based on secondary data and the author's analysis.

\section{Development}

\subsection{Case Report}

The Company Marcheluzzo (Registered as M\&C Tech) based in Isola Vicentina, Veneto, Italy, was founded in 1972, nowadays the organization is operated by the manager Valter Lain and the director Giancarlo Marcheluzzo. Marcheluzzo is a small family-owned enterprise that has always designed and built all types of automation to supply the specific niche of heavy clay industry and ceramic industry. The business has been growing up during the last years within the ceramic industry market, leveraging the company to an international prospect. Currently, Marcheluzzo has clients in South America, North America, Central America, Europe, Africa, and Asia.

Marcheluzzo has an industrial scale production that includes a production program of tunnel dryers and construction of cast shop environmental system, thermal plant, energy recovering, and other goods developed an individualized request to supply the needs of each client. In addition, the company designs and deploys the entire preparation line machinery for heavy clay industries such as ceramic of tiles and bricks. Lately, the organization is developing and producing cutting edge automation, focusing on robotics, machine learning, and digitalization.
According to the online journal $\mathrm{Zi}$ - Brick and Tile Industry International (2015) since 2012, Marcheluzzo has been working intensively on an investment project in Brazil and has set up a locally based company in Brazil, BonfantiMarcheluzzo, which is an association between both companies in order to break into the market with equipment made in Brazil using Italian cutting edge technology. This strategy has allowed Marcheluzzo to diversify the company's standard market and expand its market share in Brazil. The results have shown that it was an assertive decision because, after three years of intensive work, the business division reports contracts worth around $€ 7$ million annually, the production line is based in Leme city in São Paulo state ( $\mathrm{Zi}$ - Brick, and Tile Industry International, 2015).

Today, Marcheluzzo is a reliable organization with a great experience in the market (Heavy Clay Plants and Ceramic Plant) and a comprehensive production program, from the design \& development to the construction \& delivery of entire plants to supply the ceramic industry niche. Furthermore, the company has an extensive list of clients in Brazil, a fact that explains the geographical focus in this research linked with the marketing gaps found there.

The company invests its entire marketing communication budget in the off-line advertisement, such as brochures, trade fairs, corporate gifts, with the brand presentations, production process, quality, and partners, which promotes at various international festivals in the sector. The company has attended many trade fairs every year located in different countries, such as ANICER - Encontro Nacional da Indústria Cerâmica and ANFAMEC Expo - Feira de Negócios para Indústria Cerâmica Vermelha (Both of them are trade shows in Brazil). Thus, this is the main strategy employed by the company in order to increase leads and sales worldwide.

The company's marketing department is exclusively managed by the commercial and marketing manager, which does not have any training or educational background in this specific field, although it has many years of experience and practical knowledge related to commercial business negotiations, and sales.

Although Marcheluzzo sales results have been reasonably good in Brazil, its current communication strategy has been weak or non-existent over the years. Offline communication is restricted to only merchandising, used in special trade shows; even though the company has its website (out of service), it does not have any specialized collaborator to manage or make updates, control leads or manage all data generated from the website page, making this digital tool practically useless.

\subsection{Discussion}

The start point of the literature review covers the theme of internal consultancy in marketing because this empirical research is structured based on a marketing consultancy project for the Marcheluzzo company. 
According to the Consultancy.uk - online platform for UK's advisory and consulting industry (2020), the internal consultant is a professional that is hired to solve an organizational problem, give recommendations or implement the solutions in order to improve the performance of an organization, as well as, the internal consultant must be on the payroll or limit themselves to full-time advisory within one organization. Therefore, the researcher in this project represents exactly that concept as he was hired to contribute to the company as a catalyst to solve a specific problem related to the marketing department in order to improve its performance according to the specific objectives in this study.

Additionally, Lake (2019) states that a marketing consultant is an advisor who works to create and implement marketing strategies within companies. A marketing consultant has the task of creating a detailed marketing plan, determine a business marketing message, and identify the appropriate marketing mix to get the message out to the target market. The marketing consultant can specialize in his consultancy in a variety of areas such as online marketing, social media marketing, non-profit marketing, copywriting, print or TV advertising, public relations, and direct response marketing. Also, it is important to say that companies require marketing consultancy when they need to outsource marketing efforts and create solutions to enhance marketing activities performance.

There are numerous benefits to the organization for developing or contracting internal consulting for a company, and it can be specified in one department or various, for example, a marketing department consultancy (PHILLIPS et al., 2015). Internal consultants perform a crucial role in identifying, prioritizing, and aligning strategic initiatives within the company in order to impact the overall organization`s performance. However, there are many types of intervention practices, such as strategic, process, and operational, and change management, all of them with the same purpose, enhance the company`s performance. In this research, the consultancy model utilized is the "strategic/ business planning," according to Phillips et al (2015) this technique involves working with leadership in various or specific areas/departments of the organization to help develop and/or implement their strategic plans and major initiatives. This often includes utilizing methodologies, and for this project the following ones were utilized: business model reframing or analysis, strength, weakness, opportunity, and threat (SWOT) analysis, and brainstorming (including critical thinking and creativity thoughts). Additionally, it is necessary to have a clear strategy stating the definitions and goals. All the procedures involve developing a clear focus and its demand that the consultant makes choices and decide among different options. In order to define a clear strategy and objectives, seven steps are recommended by the 180 Degree Consulting Agency (2020): Step 1) To define a Problem, Step 2) To structure the Problem, Step 3) To prioritize Issues, Step 4) Analysis Plan and Work Plan, Step 5) To conduct
Analysis, Step 6) To synthesize Findings, Step 7) To develop Recommendations.

Furthermore, the marketing internal consultancy role in this project has the same duties listed by Thomas (2003), as follows: a) Advice: Counsel, opinions (Giving advice); b) Service: Activities completed for a specific department (Offering some kind of service); c)Information: Providing facts, data, reports (Providing information); d) New knowledge: Added value - further analysis, research (Adding something new to the organization) and e) Strategic input: Dealing with the future (adding something strategic to the organization)

Finally, as all the strategic planning types, there are no right or wrong answers to the objectives of a consultancy project, thus not either in this research. The main point is to obtain maximum benefit by making a clear decision about our objectives, roles, and operating style, consequently contributing to the company`s performance in a short or longterm period (THOMAS, 2003).

The current climate of Brazil's economy underscores the aims set out to be analyzed in this project. According to the World Bank data from 2020, Brazil is the world's ninthlargest economy in the world with a Gross Domestic Product (GDP) of US\$ 1,868.63 billion. Brazil has natural resources (e.g., iron ore) and high levels of agricultural production (e.g., soya, coffee, and sugar), all of which are important to the world economy (WALKER, 2014). GDP is growing 1.1\% annually, driven by a recovery in domestic consumption and investments. The World Bank estimates a raise of Brazil`s GDP of $2 \%$ for 2020 and $2.5 \%$ for 2021 (G1, 2020). In addition, in 2018, Brazil recorded a population of approximately 209.5 million inhabitants (WORLD BANK, 2020).

Despite these positive figures, Brazil has suffered from a lack of qualified workers, mainly in specialized areas such as engineering and science (IPEA 2012). OECD suggests that more should be done in Brazil to provide training both through the education system and by employers themselves to improve the skills supply required in the labor market (OECD 2015). It is, therefore, essential for those seeking employment to obtain competitive qualifications, which reflect the changes in the Brazilian labor market. Considering the recent technological advancements encouraged by the globalization process, Brazil needs qualified employees in its labor market to meet the demands that globalization imposes on the world (CASTRO, 2018).

Despite the significant impact of the recent economic crisis on Brazil's economy, the country continues to attract substantial foreign direct investments - FDI. FDI in Brazil increased to $\$ 88.324$ million in 2018 , highlighting, the stakes in metallurgy in which rose $45 \%$. Thus, Marcheluzzo should look at this figure with great importance. Even though the country was hit by an economic crisis, Brazil remains a powerful consumer market and, in fact, is trending upward in certain areas, such as e-commerce and mobile technology. 
Furthermore, along with developments in technology, internationalization is one of the predominant trends in present-day society, impacting citizens worldwide and therefore affecting employees, employers, and companies in general (Vestager 2000).

Looking in-depth to Marcheluzzo`s main market in Brazil, the heavy clay industry has huge importance to the country`s development, consequently to the construction field. According to the Brazilian Geography and Statistics Institute (IBGE, 2017), heavy clay and ceramic goods are used for more than $90 \%$ of brick and masonry work and roofing in the nation. The segment represents $4.8 \%$ of the construction industry and generates approximately 300.000 direct and 900.000 indirect jobs commissioned by the Brazilian Government, the sector has 6.903 companies, with an annual turnover of more than 18 billion Reais (around $€ 5.7$ billion) (MORAES, 2016). Monthly, more than 4 billion units of masonry and structural blocks are produced, including 1.3 billion of roofing ceramic tiles (GONÇALVES, 2013). Also, Brazil is one of the major international players in the ceramic tile industry, occupying the second place in the world ranking of production and consumption, with exports to over 110 countries on all the continents (EXPO REVESTIR, 2016).

To accomplish a significant result, it was necessary to answer two research questions. The first using Marcheluzzo Company as a case study, analyze the efficacy of the actual advertising budget focused on the Brazilian market. To answer this question it was necessary to build the budget based on the company`s data. In addition, the answer was based on the interview transcripts with the manager. The efficacy of the actual adv. budget within the Brazilian market is not very accurate, the company does not have a ROI analysis (Return on Investment), in order to evaluate which activity has done well and which is not doing well. However, the manager stated that the trade show investments are not generating sales. Therefore, the investments on it have been inefficient. On the other hand, the company`s visit tactic in Brazil has generated sales, even though the investments on the company's visits tend to be lower than in trade shows. Thus, the company`s visit has been a good strategy in order to gather new contracts for Marcheluzzo. Finally, the efficacy of the actual budget is undetermined. However, there are figures that can be changed, for example combining online investments to offline investments, as in that budget, there are investments only in offline marketing, which is not generating an expected sales amount to the company. Therefore, the possibilities to combine online adv. investments in a new proposed budget for Marcheluzzo, is possible.

The second question was to examine the importance of digital marketing strategies in a B2B (business-to-business) context within the Brazilian market. This question supports the general objective in this research in order to demonstrate how important the investments in digital marketing within the Brazilian marketing for the Marcheluzzo company is.
To understand the meaning and the importance of digital marketing, it is essential to start with the basic terms and how they can be understood and described. Digital marketing can be simply defined by Chaffey and Ellis-Chadwick (2016) as: "Achieving marketing objectives through applying digital technologies and media." The internet and digital technologies, in general, altered the relationships between marketers and consumers forever and did so on a global scale (RYAN, 2014).

Ryan (2014) argues that digital marketing is not only about technology, but it is all about people. In that sense, it is similar to the traditional marketing: "it is about people (marketers) connecting with other people (consumers) to build relationships and ultimately drive sales".

Furthermore, Kotler, Kartajaya and Setiawan (2017 p.38) states that

the most important role of digital marketing is to drive action and advocacy since digital marketing is more accountable than traditional marketing, its focus is to drive results where traditional marketing focus is on initiating customer interaction.

Hence, the combination of both parallels creates a new direction for customer relationships and experiences.

Thus, Digital marketing is not about understanding the underlying technology, but rather about understanding individuals, how they are using that technology in order to achieve something or supply their needs, and how marketers can leverage that to connect with them effectively. Therefore, more than only understand the technology and internet tools, understanding people is the real key to unlock the digital marketing potential (RYAN, 2014).

The Internet development, the World Wide Web, and other digital technologies have transformed marketing. For consumers, they give a much wider choice of products, services, and prices from different suppliers and a more convenient way to select and purchase goods (RYAN, 2014).

It has barely been twelve years since the first online purchase was made on a mobile phone, and it has been barely four years since ads was launched on Snapchat and Spotify (DAVIS, 2020). The replacement of social media channels can be easily seen; the interest of each channel by its user can be lost as fast as arising new channels, tools, and technologies. According to Davis (2020) developments in artificial intelligence and machine learning will shape the future of digital marketing in ways it is not possible to imagine, and probably as fast as one cannot imagine - only like one could not believe that mobile would come to exceed PC internet usage less than 20 years after internet reached phones in 1996.

Besides, the world is facing a digital transformation; consequently, a lot of development in digital marketing has been done as well. The company in this project is far behind to be innovative in a business and digital marketing sphere, even though it is modern and updated related to automation and machinery, therefore its cutting-edge products. In order 
to gain space in the market using digital marketing, it is essential to say that management processes related to the digital marketing administration include planning how digital marketing can be outperformed in order to contribute to the company and integrating with other marketing or business activities. The adoption of digital marketing also indicates a significant program of changes that need to be managed. New goals need to be set, new communications strategies developed, and staff developed through unique responsibilities and skills. Therefore, to understand, analyze, and adopt digital marketing strategies within a company it is extremely important to deeply understand what it is and how to plan and deploy it (DAVIS, 2020).

As Ryan (2014) stated, companies need a digital marketing strategy because, without one, they will miss opportunities and lose business. Even though there is a specific definition on digital marketing strategy, it should be contrasted with the definition of "strategy" that Porter (1996) in his article answered the question, "what is strategy?" then he wrote: "competitive strategy is about being different. It means deliberately choosing a different set of activities to deliver a unique mix of value.". Therefore, this definition is higher correlated to the one stated by Reyes (2020) "digital strategy is the application of digital technologies to business models to form new differentiating business capabilities." Also, it affirms that in the future, all business strategy will be a digital strategy." Yet, Alban (2016) says that "digital strategy needs to become the essence of business strategy."

Then, digital marketing strategy is defined by the Equinet Academy (2020) as a master plan or a blueprint to achieve a long-term or macro goal including a set of marketing objectives based on the market and target audiences analysis, selecting digital marketing channels and platforms, determining specific channels in order to deliver tactics, and define macro marketing KPI's to measure the performance of the digital marketing strategy (Equinet Academy 2020). Therefore, it is all based on digital channels, such as organic search, paid search, digital advertising channels, email, affiliates, social media channels, and online public relations. Chaffey and Ellis-Chadwick (2016) describe it as "digital marketing strategy is essentially a channel marketing strategy, and it needs to be integrated with other channels as part of multichannel marketing."

Ryan (2014) argues that in order to know whether the company needs to invest in digital marketing strategy, it must answer two simple questions: "Is my audience online/is it going to be online?" and "Are my products/services/brands suited to digital marketing?". Thus, contrasting those questions with the Marcheluzzo`s business environment, on can firmly say, its audience within the Brazilian market is already online and have been going online day-by-day. In addition, answering the second question is also yes, because it is possible to promote its products and brand online. Those answers can be proved from the company`s situational analysis cited in the following pages in this research.

To begin with, a strategy, according to Chaffey (2019), is necessary to elaborate on the specific objectives, linking them to the strategy itself. In order to do it, Chaffey (2019) recommends applying the technique of SMART Objectives. This is used to evaluate the suitability of objectives set to drive various strategies or the improvement of the full range of business processes.

On the other hand, Ryan says that after deciding the objectives and understand what we have to do, the next step is to define the strategy. Although Ryan (2014) highlights there is not a magic recipe to ensure your digital marketing success, and neither does anybody else. Essentially, each type of business needs its own unique strategy based on its own set of circumstances, based on products, markets, needs, and solutions.

Even though there is not a magic recipe, it is possible to plan, organize and analyze all those objectives, definitions and analysis in a clear plan in order to have accurate outcomes, Chaffey (2019) in his Smart Insight Blog recommends to apply the "PR Smith's SOSTAC $®$ Planning model," is a widely used tool for marketing and business planning, originally created in the 1990s by the writer and speaker PR Smith (CHAFFEY, 2019). Professor Philip Kotler describes it as "SOSTAC $®$ is a system for going through the steps and building a marketing plan" (SMITH, 2020). The SOSTAC@ process covers six key areas: Situation Analysis, Objectives; Strategy; Tactics; Action, and Control (CHAFFEY, 2019). Please see figure 5 below with more details about each area covered.

Having an in-depth Situation Analysis is the foundation for a great plan (SMITH, 2020). Although, Chaffey (2019) says that it should be divided as, Situation (20\%) Objectives $(5 \%)$ Strategy $(45 \%)$ and Tactics $(30 \%)=100 \%$. This author further suggests that some tips in order to efficiently use the plan, such as, use it to review your planning process and how you manage your marketing, get the balance right across SOSTAC $\AA$, summarise your situation in a SWOT analysis, make your goals SMART and link them to your analytics/ control process and summarise the entire SOSTAC $\AA$ plan within a table which combines strategies, situation, objectives, and tactics.

Companies must ensure that they are ahead of their competition in order to keep their business alive and competitive. Thus, companies cannot depend only on outdated marketing methods anymore. Business, in general, must look beyond and analyze how companies can leverage digital marketing tools to grow their reach. Digital marketing can reach an uncalculatable number of users within the digital world (SHERMAN, 2019).

The challenge for marketers is to assess which innovations are the most relevant to their organization and to seek to gain advantage through introducing them to a company such that 
the digital marketing techniques integrate effectively with traditional marketing communications. Thus, the point is not leaving apart the offline marketing, either online marketing. Sherman (2019) states that the main figures on investing in digital marketing are related to the higher level of customer engagement, ease of measuring results, bigger audience range, it is less expensive and more effective than the traditional marketing.

Brazil is the country in Latin America with the highest investment in digital marketing, according to Rocha (2019) $24.4 \%$ of the total media investments in Latin America is allocated to Brazil, against $43.5 \%$ of the global average, and Brazil has two-thirds of the entire population (more than 120 million) connected to the internet. Also, $80 \%$ of companies in Brazil are still in the early stages of digital marketing, where $23 \%$ are beginner investors in digital marketing and $57 \%$, emerging investors (ROCHA, 2019; MARTINS; TRIPOLI; GALVÃO 2019).

Social networks are strongly present in the company`s strategy in Brazil, according to Volpato (2019) based in a McKinsey research, $91.1 \%$ of the respondents (companies) have profiles and pages in the main social media channels (MARTINS, TRIPOLI, GALVÃO, 2019). It is a larger number, compared to the ones who own websites $85.7 \%$, as well as, $47.6 \%$ use SEO as a strategic tool and $31 \%$ of the companies in the research are using lead scoring.

According to Martins, Tripoli and Galvão (2019), the Brazilian digital marketing market is one of the most important in the world, and it is a critical vector for the companies growth. However, there is still a great disparity between the opportunity that digital marketing represents and the level of maturity in this discipline within companies in the country. Additionally, it is important to highlight that Brazil is one of the countries in the world with the greatest expressiveness in terms of the number of users in platforms such as Facebook, Instagram, and Youtube, and the average time spent per day on the internet in Brazil reaches nine hours per day, thus 50\% higher than in the United States, where the average is six hours a day.

On the other hand, Rock Content (2019), through its research in Brazil, says that $96.2 \%$ of participants in the research are using social media channels, and $62.6 \%$ consider social media as a key player in their digital marketing strategy. Likewise, $92.1 \%$ of internet users who answered the survey use Facebook, 92.5\% Instagram, 72.3\% YouTube, and 67.2\% LinkedIn.

Another important figure is a research by the consultancy group Bain \& Company (2017), which says that $18 \%$ ( 8 billion reais $-\mathrm{R} \$$ ) of the investment in advertising by the Brazilian companies was directed to online channels, also they predict an increase of $27 \%$ in 2020 . Thus, companies are still entering the digital marketing field in Brazil, although it has been increasing throughout the years (INTERATIVO NEGOCIOS, 2019).
Therefore, investing in Digital Marketing in Brazil is an important role for companies. Businesses, in general, can leverage the visibility and awareness of their brand, products, and services to a very large audience, or it can reach exactly their target audience using digital tools, which is almost impossible in offline advertising. Also, costs are a very important aspect. For example, with a few Reais (R\$), it is possible to boost a post on Facebook to reach tens of thousands of people (INTERATIVO NEGOCIOS, 2019).

Finally, digital marketing makes communication easier and flexible, and companies can have an immediate response from the public's reaction related to their advertisement, as well as digital strategies. It is possible to measure and evaluate each activity within online media and, thus, know exactly which one brings return to their business the most (INTERATIVO NEGOCIOS, 2019). Those figures above, are very important for this research in order to demonstrate to Marcheluzzo (2020), the importance of investing in digital marketing in Brazil.

Brazil is one of the countries in the world with the greatest expressiveness in terms of the number of users in platforms such as Facebook, Instagram, and YouTube, and the average time spent per day on the internet reaches nine hours per day in Brazil. Also, more than 120 million inhabitants

\section{Conclusion}

In conclusion, the company shows a greater interest in investing in digital marketing. However, they do not have skilled workers to deploy and manage a digital marketing strategy. For this reason, it would be more efficient for the company to contract a digital marketing agency in order to plan, develop, manage, and evaluate all the digital marketing tools.

Finally, the company is allocating greater investments in trade shows in Brazil. However, the results from that investments have not been measured, even though the manager stated, the trade show tactic is not generating expected leads. Therefore, the company has a great opportunity to invest in digital marketing, reorganize its budget and costs, and then combine online marketing and off-line marketing strategies.

Studies have tended to show only information about digital marketing concepts and the process of how to work through digital marketing, even though not aligned with other areas that are correlated to it in a practical business environment. Also, there is a lack of empirical research in those areas, demonstrating the applicability of strategies and tactics in accordance with the topics cited above. Therefore, there is a need to research and build a more concrete theoretical framework about the topics cited above.

This study contributes to the existing knowledge concerning multidisciplinary areas of advertising budget, an internal consultancy in marketing, and digital marketing. Also, it demonstrates how possible it could be the deployment of a digital marketing strategy in a company, describing step- 
by-step. However, this project provides an opportunity for additional research in this sphere.

There are a few limitations in the research process, in the interview with the commercial and marketing manager, as well as through the field observation and data collection, the company did not provide all the required data to support this research, such as ROI, market share, costs, and other financial details. Therefore, there is a limitation in this domain. However, the project has been supported by a wide range of documents. Further, this research is valid and reliable for the company and readers.

\section{References}

ALBAN, F. 4 Steps to Create a Digital Strategy. 2016. Available: https://medium.com/@fredrickalban/4-steps-to-create-a-digitalstrategy-73c84baf3d5f. Access 30 mar. 2020.

ALMADA-LOBO, F. The Industry 4.0 revolution and the future of Manufacturing Execution Systems (MES). J. Innov. Manag., v.3, n.4, p.16-21, 2016. doi: 10.24840/2183-0606_003.004_0003

BAIN \& COMPANY. Marketing Digital representa 18\% dos investimentos de mídia e deve alcançar $27 \%$ em 2020, afirma Bain \& Company. 2017. Available: https://www.bain.com/pt-br/ migration/press-releases/2017/digital-marketing-represents-ofmedia-spend-and-is-expected-to-reach-by-say--bain-company/, Access 30 mar. 2020.

BARSBY, A. Industry 4.0 and Digital Marketing: creating a digital strategy in manufacturing. E-xanthos.co.uk 2018. Available at: https://www.e-xanthos.co.uk/blog/industry-4-0-and-digitalmarketing-creating-a-digital-strategy-in-manufacturing. Access 2 mar. 2020.

BETTIOL, M.; CAPESTRO, M.; DI MARIA, E. Industry 4.0: The Strategic Role of Marketing. In: PROCEEDINGS OF THE XIV CONVEGNO ANNUALE SIM, Bergamo, Italy, 26-27 October 2017. p.1-7.

CASTRO, A.C. Investigating the impact of internationally acquired qualifications on labour market performance: the case of Brazil IOSR J. Res.Method in Education, v. 8, n.3. p.79-89, 2018. doi: 10.9790/7388-0803037989

CHAFFEY, D. What is Digital Marketing? A visual summary. Smart Insights. 2019. Available at: https://www.smartinsights com/digital-marketing-strategy/what-is-digital-marketing/ Access 29 feb. 2020.

CHAFFEY, D; ELLIS-CHADWICK, F. Digital Marketing: strategy, implementation and practice. São Paulo: Pearson Education, 2016.

DAVIS, S. [Infographic] Digital Marketing Timeline. ROI Revolution. 2020 Available at: https://www.roirevolution.com/ blog/2019/09/digital-marketing-infographic/ Access27 feb. 2020.

EQUINET ACADEMY. What is digital marketing and digital marketing strategy? 2020 available: https://www.equinetacademy. com/what-is-digital-marketing/ Access 30 mar. 2020

EXPO REVESTIR. The Brazilian Ceramic is the highlight, for the second consecutive year, of the largest design festival of the world. 2016. Available at: https://www.exporevestir.com.br/thebrazilian-ceramic-is-the-highlight-for-the-second-consecutiveyear-of-the-largest-design-festival-of-the-world. Access 13 Feb. 2020.

GONÇALVES, C. Brazil's heavy clay sector developing. Zionline.info, 2013. Available at: https://www.zi-online.info/en/
artikel/zi_Brazil_s heavy clay sector_developing 1812874 . html Access 13 Feb. 2020.

IBGE - Instituto Brasileiro de Geografia E Estatística. Pesquisa Anual da Indústria da Construção. Available at: https://www. ibge.gov.br/estatisticas/economicas/industria/9018-pesquisaanual-da-industria-da-construcao.html $?=\& \mathrm{t}=$ publicacoes. Access 13 feb. 2020

INTERATIVO NEGOCIOS. 2019. Available at: < https:// interativonegocios.com.br/component/k2/veja-numeros-domercado-de-marketing-digital-no-brasil> . Access 20 mar. 2020.

KOTLER, P., KARTAJAYA, H.; SETIAWAN, I. Marketing 4.0: moving from traditional to digital, NY, USA: Wiley., 2017.

LAKE, L. Marketing Consultant Role and Responsibilities: the skills marketing consultants need to be successful. The Balance Small Business. Available at: https://www.thebalancesmb.com/ what-is-a-marketing-consultant-2295290 Access 22 feb. 2020.

MARCHELUZZO. Wehsite. 2020. Available: https:// marcheluzzo.com/ Accessed 26th feb. 2020.

MARTINS, H.; TRIPOLI, M.; GALVÃO, L. O estado do marketing digital no Brasil: 14 alavancas para atingir a maturidade. McKinsey \& Company. 2019. Available at: <https:// www.mckinsey.com/br/our-insights/o-estado-do-marketingdigital-no-brasil-14-alavancas-para-atingir-a-maturidade $>$ Access 20 mar. 2020.

MORAES, N. Ceramics in Brazil. Zi-online.info, 2016. Available at: https://www.zi-online.info/en/artikel/zi_Ceramics in Brazil_2595768.html Access 13 feb. 2020.

REYES, C. Digital Strategy: the evolving business strategy liferay. Available at: https://www.liferay.com/resources/1/digitalstrategy Access 29 feb. 2020.

ROCHA, R. Marketing digital: 80\% das empresas estão só começando. Meio Mensagem, 2019. Available at: <https://www. meioemensagem.com.br/home/marketing/2019/02/05/como-vaio-brasil-em-marketing-digital.html> accessed 20 mar. 2020.

PHILlIPS, J.; TROTTER, W.; PHILLIPS, P. Maximizing the value of consulting: a guide for internal and external consultants. Hoboken: Wiley, 2015. doi:10.1002/9781119154846

ROCK CONTENT. Inteligencia Corporativa, 2019. Empresas e Usuários nas Redes Sociais. Available at: <https://inteligencia. rockcontent.com/social-media-trends-2019-panorama-dasempresas-e-dos-usuarios-nas-redes-sociais/> Access 20 mar. 2020.

RYAN, D. Understanding Digital Marketing: Marketing strategies for engaging the digital generation. London: Kogan Page Limited, 2014.

SHERMAN, L. Digital Marketing Vs Traditional Marketing: which produces greater ROI?. Digital Marketing Blog. 2019. Available at: <https://www.lyfemarketing.com/blog/digitalmarketing-vs-traditional-marketing/> Access 18 mar. 2020.

SMITH, P. SOSTAC $®$ Planning|PR Smith. Prsmith.org. 2020. Available at: https://prsmith.org/sostac/ Access 1 mar. 2020.

VOLPATO, B. Pesquisa traz dados sobre maturidade de empresas brasileiras em Marketing Digital e Vendas. Blog de Marketing Digital de Resultados. 2019 Available at: <https:// resultadosdigitais.com.br/blog/pesquisa-maturidade-domarketing-digital-e-vendas-no-brasil/> Access 20 mar. 2020.

WALKER, A. Whatever happened to the BRICS economies. 2014. available: http://www.bbc.com/news/business-29960335 Access 30 nov, 2020.

WORLD BANK. 2020. Available: http://www.worldbank.org/en/ country/brazil/overview\#1 Access feb. 2020. 